\title{
Pecking Order Theory as a Strengthening Capital Structure
}

\author{
Marista Oktaviani ${ }^{1}$, Mochamad Mochklas ${ }^{2}$, Ezif Moh. Fahmi ${ }^{3}$ \\ \{maristaokta48@gmail.com ${ }^{1}$, mmochklas@gmail.com² , ezifahmi25@gmail.com ${ }^{3}$ \} \\ Universitas Muhammadiyah Surabaya ${ }^{1,2,3}$
}

\begin{abstract}
The purpose of this study is to determine the pecking order theory as a reinforcement of capital structure based on consumption sector companies that are listed on the IDX. This research uses dividend policy moderation which influences growth on capital structure. The 2014-2017 research period collected data using documentation techniques with a sample of 122 consumption sector companies listed on the IDX, data analysis using WarpPLS. The results of ROE and Current Ratio have a significant positive effect on capital structure, growth has a positive but not significant impact on the capital structure, and dividend policy cannot moderate the growth of capital structure.
\end{abstract}

Keywords: capital structure, return on equity, current ratio, growth, dividend policy

\section{Introduction}

Competition of companies in developing countries, one of them is Indonesia. The consumption sector companies have experienced excellent growth year after year. Processing a company that is carried out by company management, which includes funding decisions for ongoing operations in daily life. Resolution on the use of funds in company operations using funding from internal and external parties. Processing is related to growth, an increase in selling value or even the capital costs incurred by the company are called the management of capital structures correctly and adequately. Optimizing the capital structure in the company can be seen from the conditions in which the company plays a role in the use of external funds or debt and equity management.

The theory that supports capital structure according to (Brigham \& Houston) is that pecking order theory has the assumption that companies are better off using funding from private companies, companies adjust dividend distribution, dividend policy increases profitability, external funding. Pecking order theories have a sequence of funding sources (1) internal financing of retained earnings, (2) debt usage with bond issuance, (3) publication of shares.

Franco Modigliani and Merton Miller (MM) introduced a capital structure theory model with several assumptions: 1) no tax. 2) investors can borrow at the same level as the company. 3) information is always available to all investors and can be obtained at no cost. 4) EBIT does not affect the use of debt. Factors that influence the capital structure so that it can determine the right capital structure, among others, profitability by using return on equity, current ratio, and growth. Profitability is the company's ability to generate profits; in this study, profitability is represented by Return on Equity (ROE).

This study discusses the factors that influence the capital structure; researchers take consumer goods industry objects because consumption companies can reduce almost $50 \%$ of 
the growth of the manufacturing sector in 2017. The reason researchers use these variables is that there is a research gap between the results of previous studies while the renewal of this research is the dividend policy used as a moderating variable. Therefore this study was conducted to determine whether the results to be obtained later can be close to the results or different results with previous studies.

\section{Hypothesis}

\subsection{Effect of return on equity on capital structure}

ROE is a return on equity; high profits can indicate the scope of benefits obtained by the company, so the company can fund its operations from the company's internal without adding funds from outside capital. Pecking order theory explains that it is better to use domestic funds than external for the company's operations. The results of research (putri; Wulandari; Prasetya $\&$ asandimitra) ROE have a positive effect on capital structure. The hypothesis in this research is "ROE has a significant positive effect on capital structure", then this hypothesis is H1.

\subsection{Effect of current ratio on capital structure}

Current ratio where company assets can be used to pay existing debt. The more significant the present proportion, the higher the company's ability to cover the existing deficit. The high current ratio shows that too much cash is due to the amount of profit or there is no commercial use for investment activities, so the pecking order theory explains it is better to use internal funding first. The hypothesis in this research is "Current ratio has a positive effect on capital structure", then this hypothesis is $\mathrm{H} 2$.

\subsection{Effect of growth on capital structure}

According to (Brigham \&houtson) companies with rapid growth tend to use more debt than companies that grow slowly. But the results of (alib) and (Astuti) growth do not affect the capital structure because the high and low growth rates do not guarantee that the company gets high profits as well. The hypothesis in this research is "Growth hurts capital structure", then this hypothesis is $\mathrm{H} 3$.

\subsection{Dividend policy moderates the effect of growth on capital structure}

Growth is measured by changes in total sales from the previous year. The existence of high company growth, the company needs more funds to support growth. At the time of high growth, dividend policy can strengthen in improving the capital structure because when the company grows, shareholders believe that the company's growth can get high dividends, even though funding comes from debt. The hypothesis in this research are "Dividend policy can moderate growth towards capital structure", then this hypothesis is H4. 


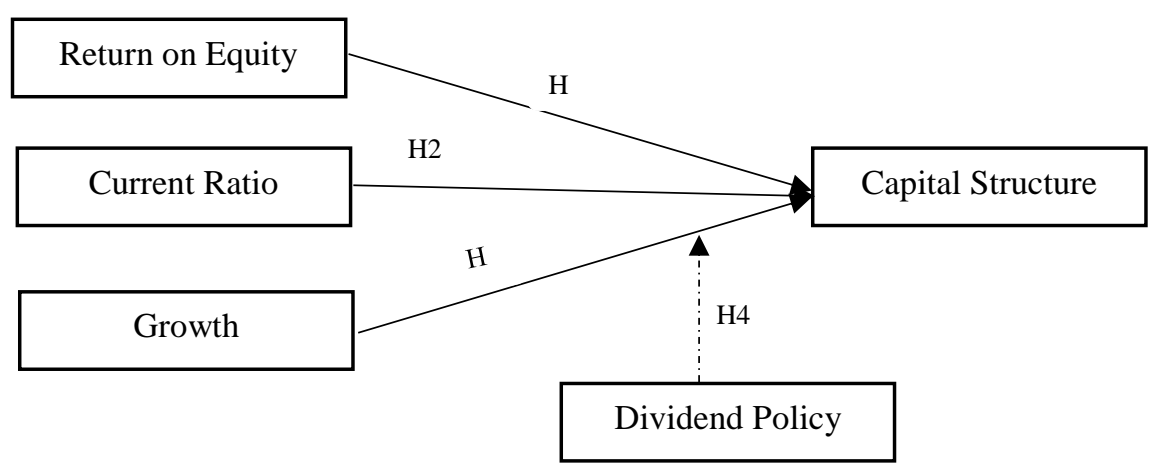

Fig 1. Thinking Framework

\section{Method}

\subsection{Objects of research and sampling techniques}

The object used in this study is a consumer goods sector company listed on the Indonesia Stock Exchange in 2014-2017. The type of data used is secondary data in the form of financial statements that are listed on the Indonesia Stock Exchange in 2014-2017. Data collection uses documentation techniques. Determination of the sample in this study using purposive sampling with criteria: (a) consumer goods sector companies in 2014-2017 listed on the IDX, (b) companies that publish financial statements in rupiah, (c) companies that have data by the variable this research. The number of samples in this study was 122 samples.

\subsection{Operational Definition of Variables}

Dependent Variable

The dependent variable in this study is the capital structure. The capital structure formula uses debt to assets: capital structure $\frac{\text { to debt }}{\text { to asset }}$.

Independent Variables

Return on equity $=\frac{\text { net } \text { profit }}{\text { to equity }}$

Growth $=\frac{\text { sales }(t)-\text { sales }(t-1)}{\text { sales }(t-1)}$

Current Ratio $=\frac{\text { current assets }}{\text { current debt }}$

Moderating variable

The moderating variable in this study is the dividend policy. Dividend policy is measured by dummy where value 1 is stated that the company distributes dividends and the value of 0 is stated that the company does not distribute dividends. 


\subsection{Data analysis technique}

The data analysis technique in this study used SEM analysis, with the test method using the WarpPLS test tool. Data analysts using 2 models are the outer model and inner model. Hypothesis testing uses probability values and $\mathrm{t}$-statistical values, with p-value with alpha $5 \%$. The alpha t-table value of $5 \%$ is 1.96 . Equations in research:

$$
Y=a+\beta_{1} X_{1}+\beta_{2} X_{2}++\beta_{3} X_{3}+\beta_{4} X_{3} Z_{1}+e
$$

Note:

$\mathrm{Y}=$ Capital Structure

$\mathrm{a} \quad=$ constanta

$X_{1}=\mathrm{ROE}$

$X_{2} \quad=$ Current ratio

$X_{3} \quad=$ Growth

$Z_{1} \quad$ = Dividend policy (Moderating)

\section{Result}

\subsection{Outer Model}

Table 1. Fit Model

\begin{tabular}{cc}
\hline Statistic & Sign. \\
\hline APC $=0.297$ & $\mathrm{P}<0.001$ \\
ARS $=0.655$ & $\mathrm{P}<0.001$ \\
AVIF $=1.174$ & Good if $<5$ \\
\hline
\end{tabular}

The fit model is shown in the table above with APC 0.297 P-Value $<0.001$, ARS 0.655 and $\mathrm{P}$ value $<0.001$. The AVIF value of 1.174 fulfills the requirements of $\leq 5$; the research data is tested with the fit model, and the research data is declared fit so that the data of this study do not occur multicollinearity.

Table 2. Path coefficients

\begin{tabular}{lcccccc}
\hline & SMO & ROE & CR & DEV & GROWTH & DEV*GROWTH \\
\hline SMO & & 0.426 & 0.640 & & 0.061 & -0.059 \\
ROE & & & & & & \\
CR & & & & & & \\
DEV & & & & & & \\
GROWTH & & & & & \\
$\quad$ DEV *GROWTH & & & & & \\
\hline
\end{tabular}


Table 3. P-Values

\begin{tabular}{|c|c|c|c|c|c|c|}
\hline & SMO & ROE & $\mathrm{CR}$ & DEV & $\overline{\text { GROWTH }}$ & DEV*GROWTH \\
\hline SMO & & $<0.001$ & $<0.001$ & & 0.289 & 0.193 \\
\hline ROE & & & & & & \\
\hline CR & & & & & & \\
\hline DEV & & & & & & \\
\hline GROWTH & & & & & & \\
\hline DEV ${ }^{*}$ GROWT & & & & & & \\
\hline
\end{tabular}

The path coefficient and p-value ROE value for the capital structure coefficients 0.426 and p-value $<0.001$ stated ROE has an effect on the capital structure, the current ratio also affects the capital structure with 0.640 factors and p-value $<0.001$, but growth cannot influence capital structure with 0.061 coefficients and $\mathrm{p}$-value -0.289 because of a significant value of more than 0.05 .

\subsection{Moderation test}

The effect of growth on the capital structure with a value of 0.29 coefficients shows that growth has a significant effect on capital structure, while the interaction of dividend policy to moderate growth on capital structure has a ratio of 0.19 indicating that dividend policy cannot moderate or strengthen growth towards the capital structure.

\subsection{Inner model}

Testing uses an inner model where this model is used to measure structural models. The existence of this test to see or connect between latent variables

Table 4. Inner Model

\begin{tabular}{lcccccc}
\hline & SMO & ROE & CR & DEV & GROWTH & DEV*GROWTH \\
\hline R-squared & 0.655 & & & & & \\
Comp. Reliabilty & 1.000 & 1.000 & 1.000 & 1.000 & 1.000 & 1.000 \\
Cronbach's alpha & 1.000 & 1.000 & 1.000 & 1.000 & 1.000 & 1.000 \\
Average Var Extrac & 1.000 & 1.000 & 1.000 & 1.000 & 1.000 & 1.000 \\
Full colline VIFs & 1.403 & 1.624 & 1.170 & 1.343 & 2.379 & 2.394 \\
Q-squared & 0.667 & & & & & \\
\hline
\end{tabular}

Inner model is to find out one variable influences other variables. The $\mathrm{R}$-squared value is 0.655 or $65 \%$ which means that the influence of the independent variable on the dependent is very strong at $65 \%$, the VIFs value based on the table above is below the 3.3 value, this shows the model is free from collinearity and the standard method bias while the Q-squared value is 0.667 or $67 \%$. 


\section{Discussion}

\subsection{Effect of return on equity on capital structure}

The results of the H1 study were accepted, $\beta=0.43$ and $\mathrm{P}<0.01$ means that ROE has a significant positive effect on the capital structure. This means that the size of the profits obtained by the company will determine the level of corporate debt in the capital structure. The results of this study are supported by the results of previous research by (wulandarai) and (Nurrohim).

\subsection{Effect of current ratio on capital structure}

$\mathrm{H} 2$ results were accepted, with the value of $\beta=0.64$ and $\mathrm{P}<0.01$, which means that the current ratio has a significant positive effect on the capital structure. The current ratio is the ratio between current assets and current debt. The high current ratio is not necessarily able to pay the company's debt because in terms of current assets is not profitable, for example, there is a large balance of accounts receivable which may be difficult to collect

\subsection{Effect of growth on capital structure}

The results of the H3 study were accepted, with $\beta=0.06$ and $\mathrm{P}=0.29$ which means that growth does not have a significant effect on the capital structure. The company's growth will reduce the number of liabilities and the capital structure will decrease. Increased sales in the company automatically profit also increases. Companies will continue to use internal funds rather than using debt because companies with high growth often face greater uncertainty and tend to reduce their desire to owe (Brigham \& Houtson, 2001). Therefore the company avoids debt because companies are afraid that they cannot pay and only pose a risk. The results of this study are supported by (Kusuma \& Suhadak), (prasetya \& Asandimitra) and (Astutui) stating that growth does not affect the capital structure.

\subsection{Dividend policy moderating growth to capital structure}

The results of the H4 study were rejected, that dividend policy cannot moderate growth with capital structure. Good company growth does not necessarily use funds from internal companies, but in operational activities using funds by using debt or taken from external parties so that the capital structure rises. But the dividend policy is not able to moderate the growth with the capital structure because companies that have high growth do not necessarily get maximum profits, so the company does not necessarily distribute dividends.

\section{Conclusion}

The study entitled return on equity, current ratio and growth affect the capital structure of ROE research results, and the current ratio has a significant positive effect, while growth has no effect on the capital structure and dividend policy cannot moderate or strengthen the influence of growth on capital structure. 
Suggestions for future researchers to use other variables, which can be used as moderation, and use different proxies to measure the variables above and use different test models such as Lisrel, etc.

\section{REFERENCE}

